\section{Graphic Making, Actuarial Knowing: Transfer and Countertransference in Frederic Edwin Church's South American Drawings}

Matthew C. Hunter

McGill University, Canada

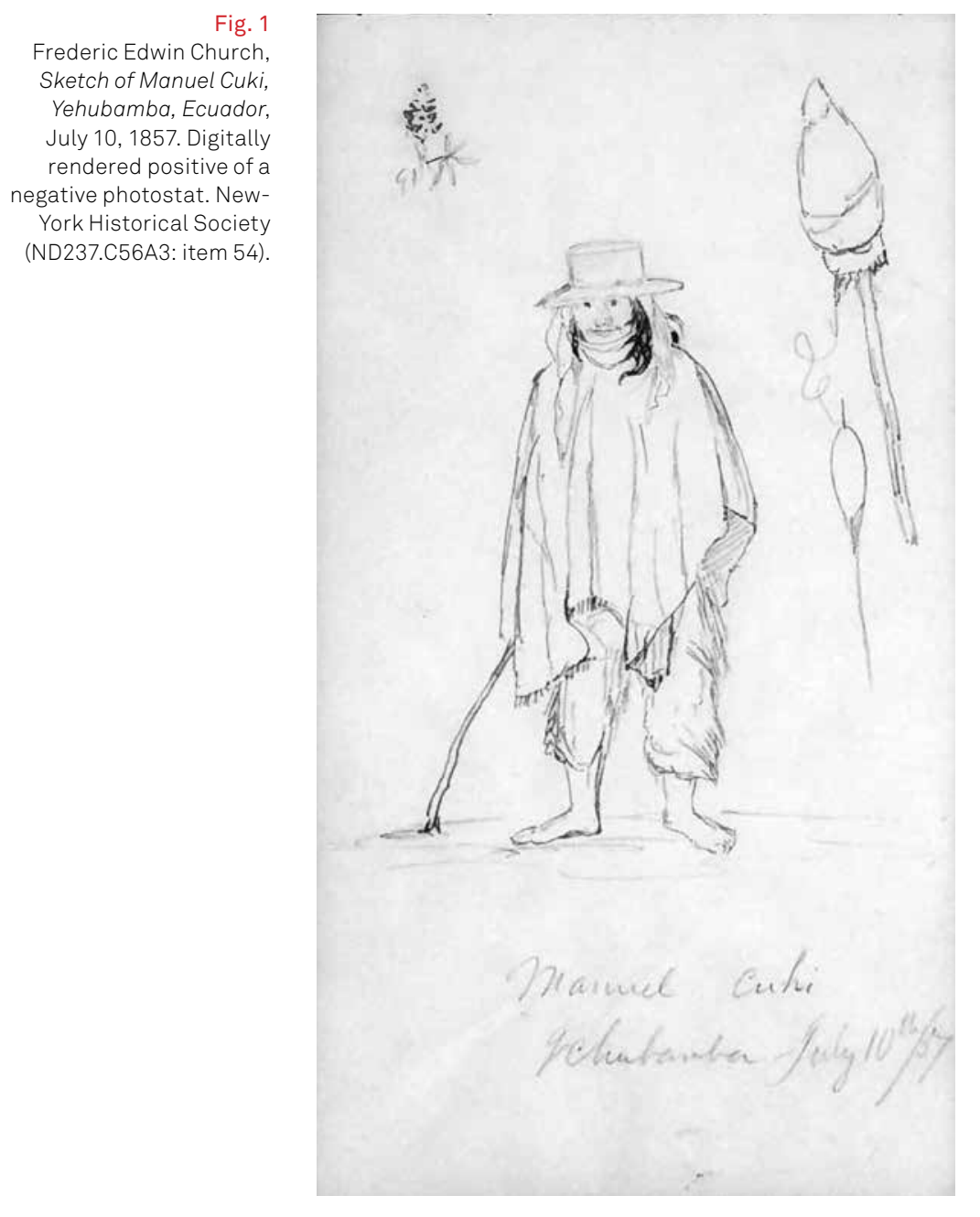

o occlude his arms and hands entirely. From the roughly triangular, tented fall of his cape and the position of his shadow-casting walking stick at left, the beholder might even infer that the figure's hands are behind his back.

Although Church has thus hidden prominent markers of personal identity—if he has reduced suggestion of context to the barest, arched delineations of ground underfoot-his light sketch heaves with information nonetheless. In its front facing posture of an isolated figure plotted on the page's vertical axis, the

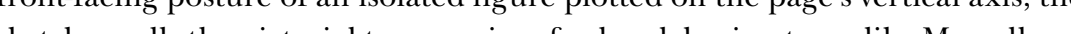
sketch recalls the pictorial taxonomies of urban laboring types like Marcellus Laroon's Cries of London (168) or Henry Mayhew's Lond on Labour and the London Poor (1851; fig. 2). ' That generic presentation frequently juxtaposed the laborer's depiction with a verbal evocation of sound: the vendor's "cry," or distinguishing, audible pitch for hawking wares that would be subscribed as a textual legend. Rather than evoking speech, Church uses text to name his subject and to locate their dated encounter. The inscription "Manuel Cuki, Yehubamba, July 10th/57" reads out in the painter's slanting hand at lower right. 


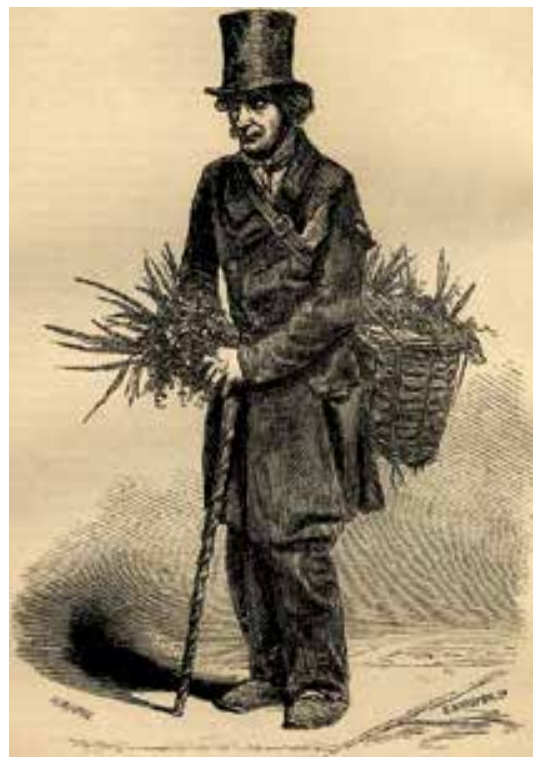

Fig. 2

Ebeneezer Whimper, after $\mathrm{H}$

W. Hine, The Groundsel Man.

Mayhew's London Labour an

the London Poor [London:

Charles Griffin and Company

public domain).

Squared to the vertical axis, Cuki's staunch form competes for visual space with an outsized detail at upper right: a tufted distaff and spindle, joined together by a coiling thread. Out of scale with Cuki's body, these instruments of textile production might equally appear out of time. For, during his first voyage to South America in 1853, Church had observed the manufacture of Andean tunics by means that looked positively archaic to a native habituated to the Connecticut River valley's bustling textile mills. From modern-day Colombia in August 1853, the painter had written: "Pasto is famous ... for its manufactures particulary for $R$ uanas or the native costume of the men[] Yet so rude are their inturly for that for makng they] twirl the spindle with their fingers. "While a near-contemporary British-born artist such as John Lockwood Kipling could look upon the native techniques of textile production he observed in colonial India as high-quality indigenous skills threatened by modern, imperial industry, Church saw less a loss of tradition than of time (fig. 3). ${ }^{3}$ Writing to his mother in 1853 , the painter calculated that disjunction between labor time expended and market value accrued this way: "A fine ruana requires six months work often[;] and yet the best seldom bring more than eight or ten dollars."

When drawing in 1857, Church made little effort to stitch his portrayal of a tunic-wearing native into the same pictorial fiction as the outscaled instruments for producing native tunics. Instead, his spot sketch stages a paratactic collision between a figure named and dated in the present with observations and numerical values recalled from nearly four years earlier. Yet, like the cleavage of time and pictorial space between Cuki and the instruments of textile production, Church also had the means to thematize that gap between his depicted subjects-and to do so in terms of conflict. When in Bogotá in June 1853, Church had witnessed a street fight between partisans whom he distinguished by their competing, class-identified garments. So he then wrote his father: "The city is thrown into considerable excitement lately by a difficulty between the cachacas and the ruanas. The former means the better dressed young men and the latter the class of people who wear ruanas." If a flowing, Andean tunic was thus a metonym for the working-class supporters of General José María Melo who bodied forth violently by the thousands from Bogotá's Las Nieves district on July 8, 1853, then Church's drawing of July 10, 1857, returns that symbol to its inhabited presence and its me pain painter depics salicn, visible features of an individal whose name, place, and observed date he records. Then, he links his subject by graphic means to archaic weaving instruments whose time-intensive manipulation stands opposed to the market value of their yield. And, as that yield is the garment dominating Cuki's body, so those undervalued means of textile making visually overshadow and, in turn, perceptually overdetermine the social class to which Church's subject can be assigned.

How should we understand operations like this? Church's material inferences appear strangely asynchronous. At once, his act of sizing Cuki up evokes the peuring of com formulation of the period eye: where habituated, mathematical skills key to fifteenth-century Florence's mercantile economy find privileged expression in the emphasis on mass and volume of the city's celebrated visual art. "As a man gauged a bale, the painter surveyed a figure," Baxandall put it. "In both cases there is a conscious reduction of irregular masses and voids to combinations of manageable geometric bodies. A painter who left traces of such analysis in his painting was leaving cues his public was well equipped to pick up."' Church's fabulous commercial success gives ample ground to suppose that his pictorial cues and the judgments generating them might have accorded well with a midnineteenth-century American period eye. Yet, in that way, the painter's front-

John Lockwood Kipling Carpet Weavers in Amritsa India, 1870 . Pencil, pen (๑) Victoria and Albert Museum, London

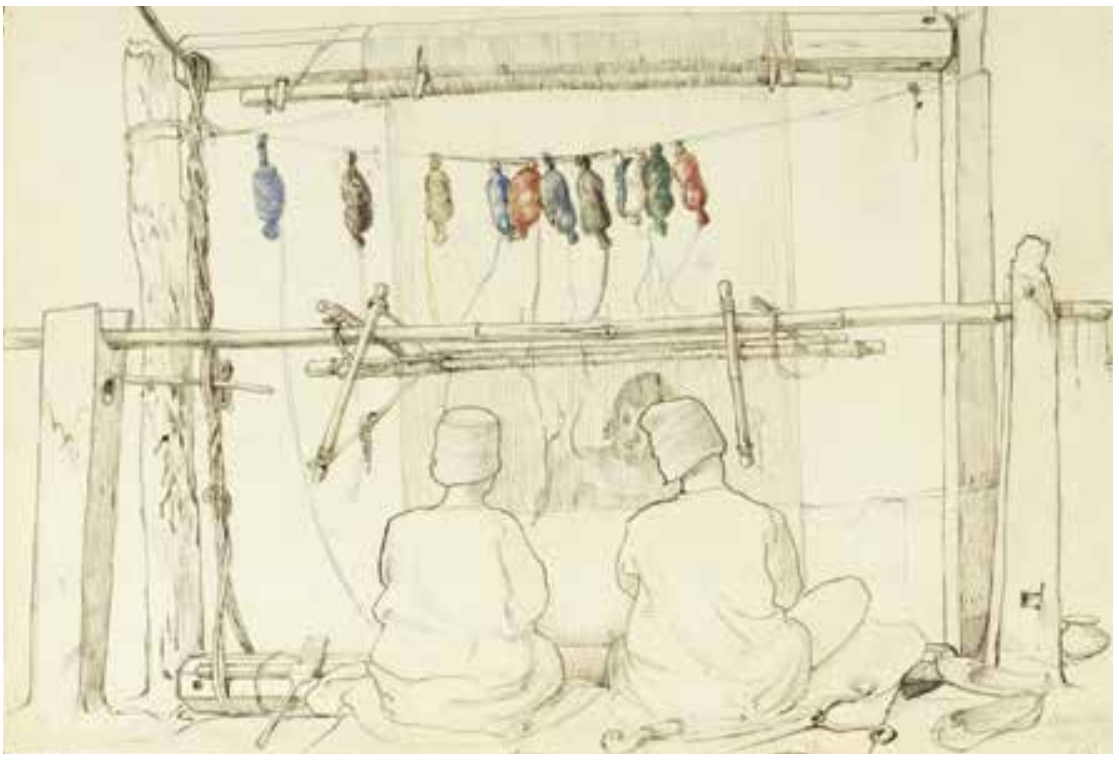


his period's mechanical objectivity, anticipating instead the physiognomic sight of trained judgment that Lorraine Daston and Peter Galison attribute to early twentieth-century epistemic regimes. ${ }^{8}$ I stress this temporal to and fro to foreground the speed at which Church seems to have exercised his summary sizing, or "thin-slicing," of Cuki: that rapid cognitive analysis (popularized by Malcolm accuracy from minimal information base. ${ }^{9}$

If the basic analysis of the Yehubamba sketch holds at least provisionally, then that reading also chafes against usual stories told about Church's graphic practice. First, the synthesis en plein air $\mathrm{I}$ have plotted for Church flies in the face of the temporal orientation often assigned to his drawings. Church's extensive corpus of on-site drawings is frequently seen as graphic means to pictorial end: dilations of vernal, rural perceptual attention made to be consulted again and again in the hibernal, metropolitan studio where the painter synthetically produced his huge, lavishly detailed exhibition pictures such as The Heart of the Andes (1859; fig. 4) ${ }^{10}$ These sketches are layered with skeins of information often turned under the

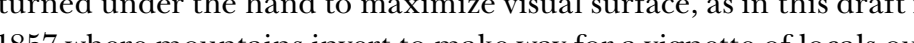
1857 . anda, Ecuador (fig. 5). Thus, it remains an open question whether the kinds of snap judgment I've proposed in the Yehubamba sketch would have fit easily into a graphic practice made capaciously observant on-site, anticipating its reuse in the studio as props for finished oil paintings. Second, and more directly: for all the foregoing talk of Cuki, captions, and capes, nothing has yet been said about a fourth cluster of graphic information visible in the sketch. What is to be made of that weird, stabby vegetal form at upper left, which Church appears to have annotated (or numbered) at least partially? Surely any viable assessment would

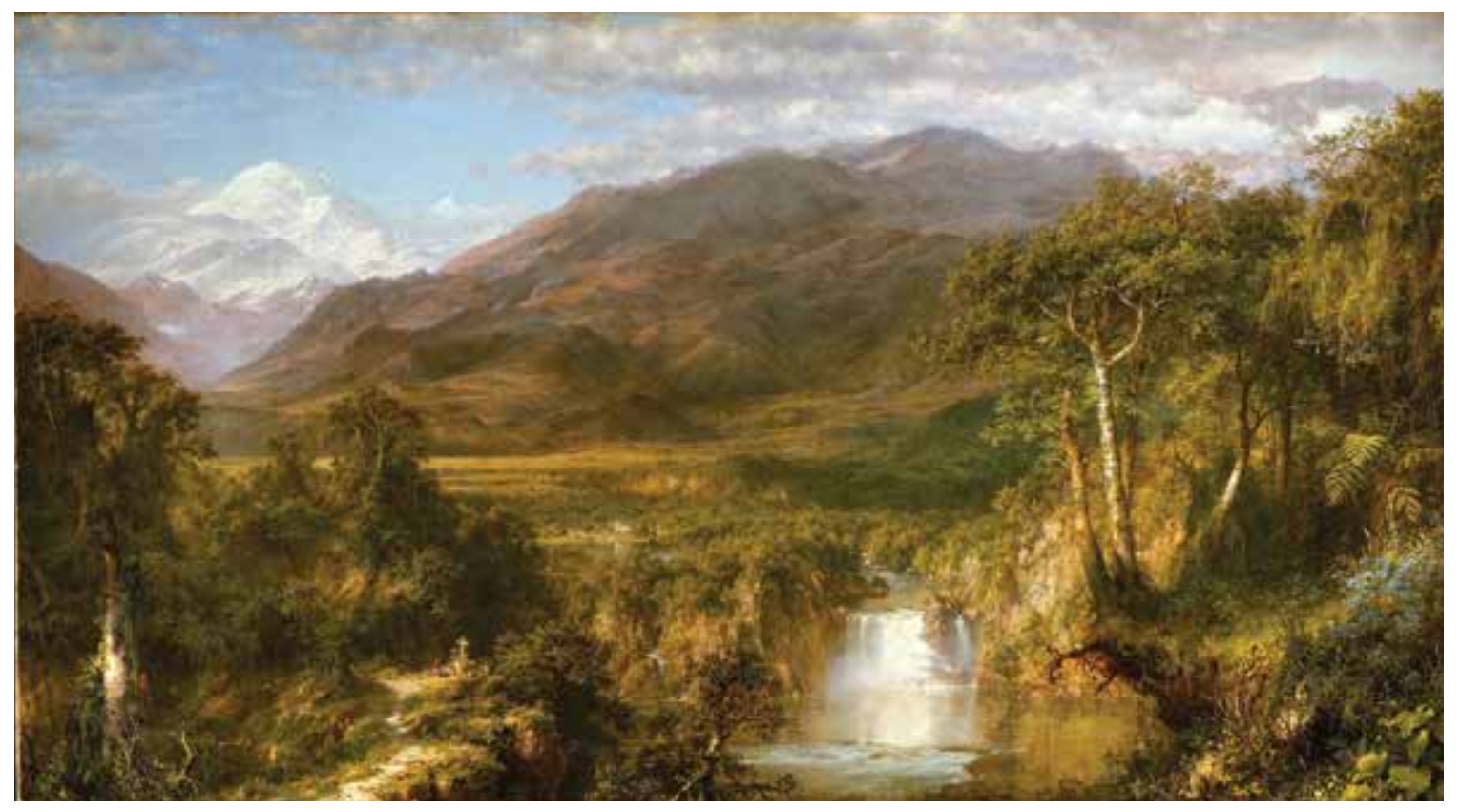

Frederic Edwin Church, The Oil on canvas. Metropolitan Museum of Art (Bequest of Margaret E. Dows, 1909.09.95; artwork in the

via www.metmuseum.org).

Frederic Edwin Church. Andean Foothills near Guaranda, Ecuador, June 4 , on light-gray-green pape, $113 / 4 \times 18$ in. Collection lana State Historic Site (OL.1977.129, New York State and Historic Preservation).

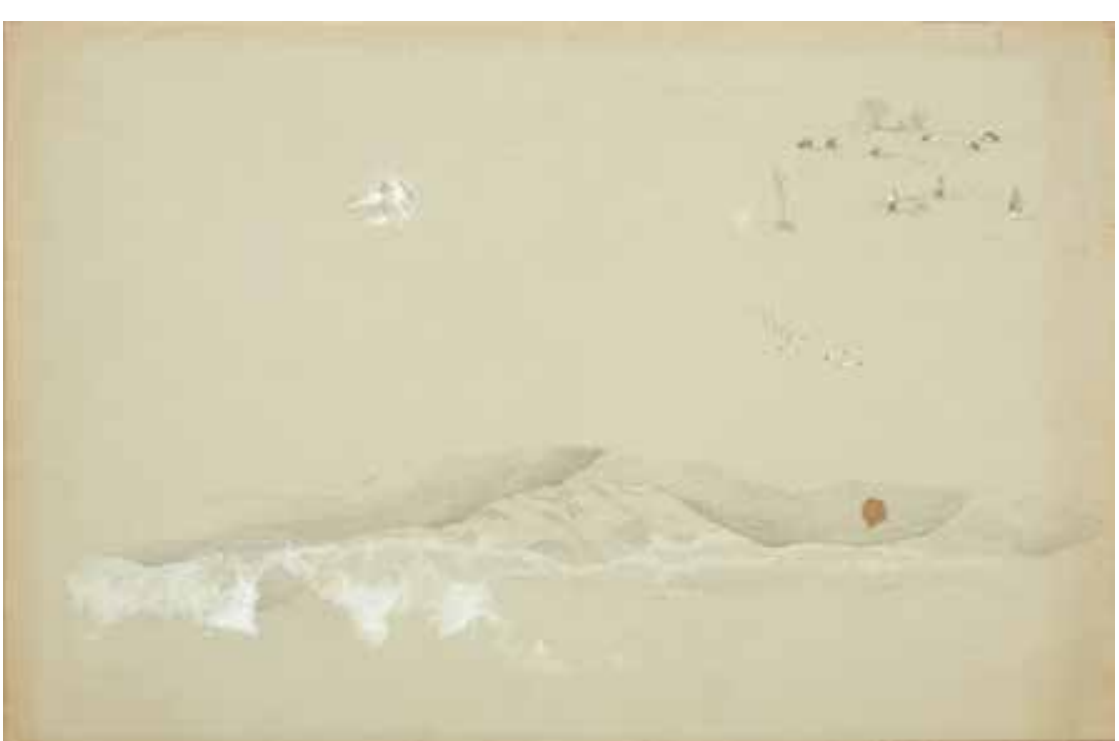

need to account for all of these features before broader appeal to "cognitive style" could be warranted. ${ }^{11}$

And this is where matters get tricky, for the sketch as presented thus far is a feint. It is a digital inversion of a photograph of a negative photostat now in the collection of the New-York Historical Society (fig. 6). This is the only form in which Church's Yehubamba sketch appears to survive. The drawing Church made of Cuki on July 10, 1857, occupied one page in an unusual, multisite sketchbook, conjoining conjoining the past New York, the Lkt New York, the sketchbook was photostatted at the New-York Historical Society in June 1949. It has since gone missing and figures nowhere (so far as I can tell) in the extensive, meticulous research on Church's art. Surely, it will be objected, this absence represents an ignominious end to my art-historical story, requiring a significant climb-down from any further claims. After all, no less an authority than Heinrich Wölfflin served disciplinary warning against reliance on reproductive technologies particularly when studying drawings—graphic figures all too easily skewed into the camera's own painterly image. "We are so used to see everything from the painterly angle," Wölfflin cautions, "that even when confronted with linear work of art, we apprehend the form somewhat more baly han was intended, and where mere photographs are at our disposal, painterly lurring goes a stag (reproductions of reproductions)."12

The aim of this article, however, is not to contribute an addition to the corpus of Churchiana. Instead, I take this modest drawing's sestgat tunity to learn as much about the painter's ways of making and knowing as to pose a methodological problem of art history's technics. What might be seen in Church's drawing practice if we take the material translation of his sketches of 


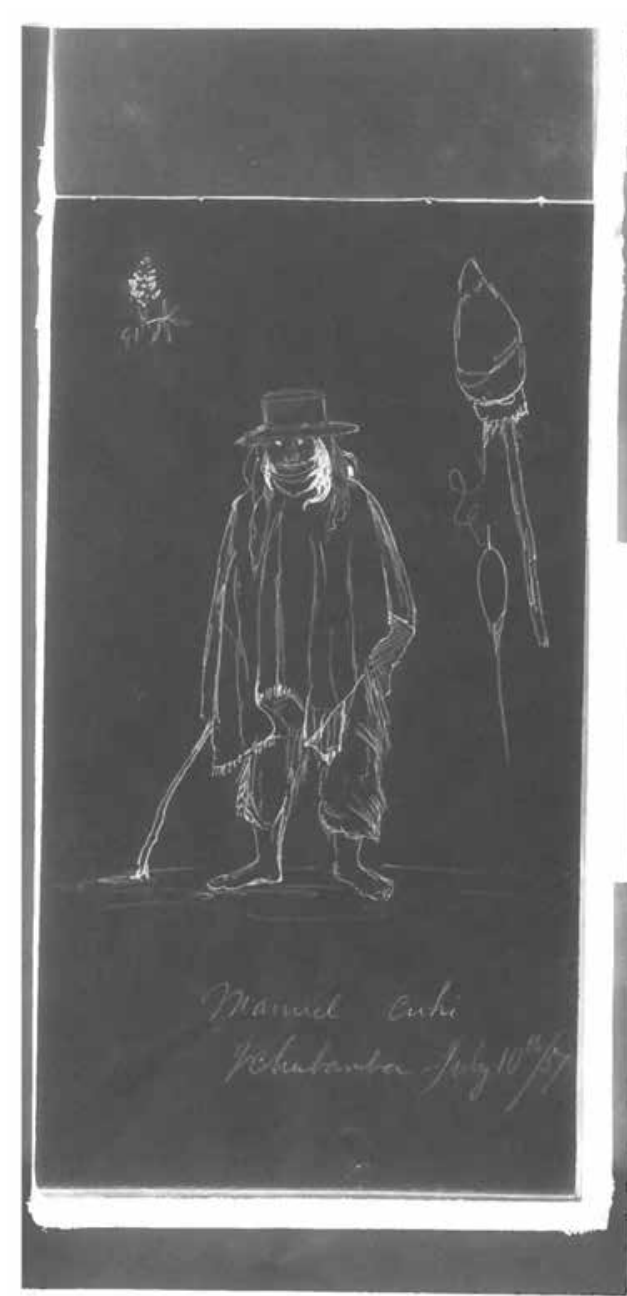

Fig. 6

Frederic Edwin Church,

Yehubamba, Ecuador, July

10, 1857. Negative photostat.

New-York Historical Society

Manuel Cuki and other South American targets not as sites of evidentiary aporia but as mediated affordances? How could the drawing's historical transfer into photostat allow us to think again about Church's draftsmanship more broadly conceived? What, in short, might a negative photostat make positively visible of the technologies driving art-historical knowledge production? As should be clear from the asymmetry between such weighty questions and the slightness of the Yehubamba sketch, my own attention to this material transfer is hardly disinterested. In my conclusion, I will also attempt to come to terms with my own countertransference onto this transfer through the photostat's penumbra.

\section{Picture, Text, Number}

Some two weeks before his graphic encounter with Manuel Cuki, Church made a sketch of the Andean peak of Cayambé from the outskirts of Quito, Ecuador (fig. 7). Cayambé rises as a humpback ridge, with Church's pleated pencil lines

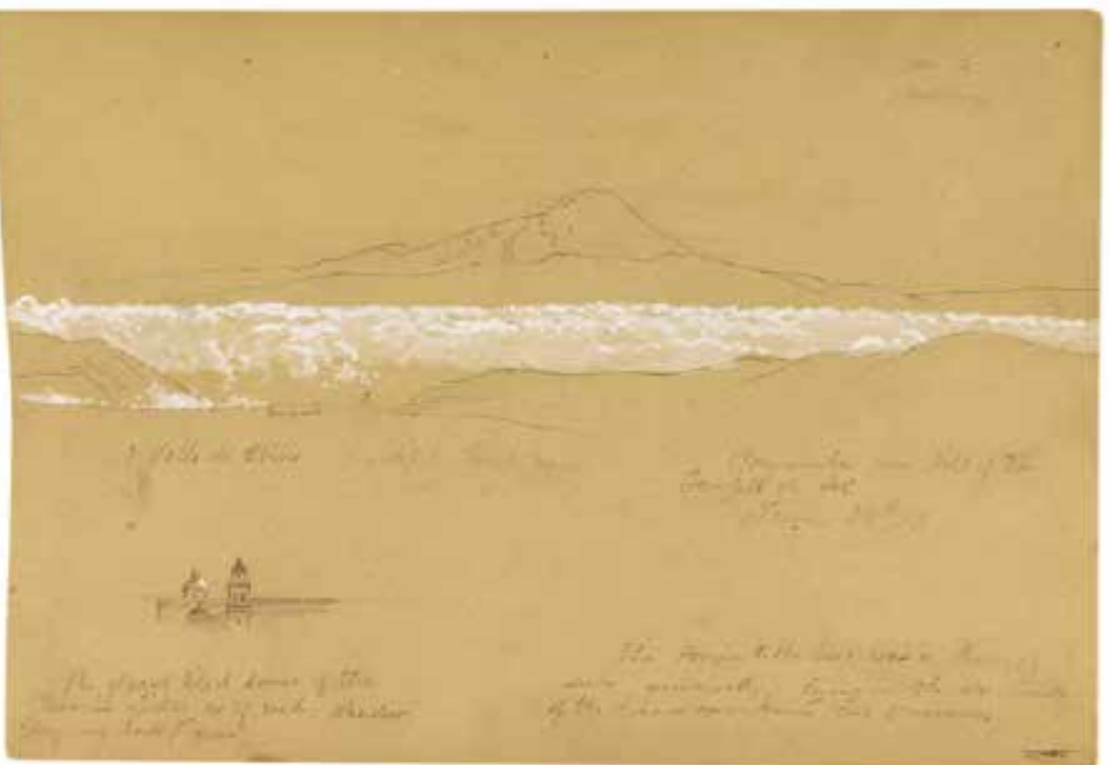

etching and cinching in descent at right to denote its snowcapped peak. Below, a hick, horizontal cordon of undulating gouache strokes float on a bed of wash to read as a bank of mist, which ascends in cottony wisps from the intervening valley. Into this spare study Church has introduced a strategy typical to his drawing practice in the 1850s. He has inset a small study of a domed church and its bell tower at lower left, while littering the page with textual annotations. As noted along the page's bottom edge: "The glazed tiled domes of the churches glitter as if wet, shadow being very dark (green)."

This presence of text in the pictorial field manifests in a literal way an elective affinity between writing and picturing crucial to recent studies of nineteenthcentury American art (fig. 8). Examining the obsession with images of writing and notational systems in the work of Thomas Eakins, Michael Fried has influentially interpreted nineteenth-century American painting as a vexed, pathological misreading of the implications of French realist painting. ${ }^{13}$ By Fried's account, Eakins's project in The Gross Clinic is cloven by a desire to reconcile a "vertical" structure of chromatic, pictorial perception against a "horizontal" graphic plane of writing and drawing. an ultimately Oedipal tension that Fried traces back to Eakins's relations with his father, a writing master. ${ }^{14}$ For its part, Church's project (a) if the licked, inge of the licked, immaculate facture of exhibition pictures like The Heart of the Andes exemplifies supremely that drive to make paintings appear "breathed on air or formed out of plasma" enacted under the medium-repressing spell of what Clement Greenberg once called "literature," an aspiration to the condition of writing was a desideratum Church shared widely with fellow mid-century landscape painters. ${ }^{15}$ Likening the novice painter to a schoolboy learning the rudiments of literary composition, Asher B. Durand condensed hoary tropes drawn from millennia of Horatian and natural-historical tradition-all filtered through 


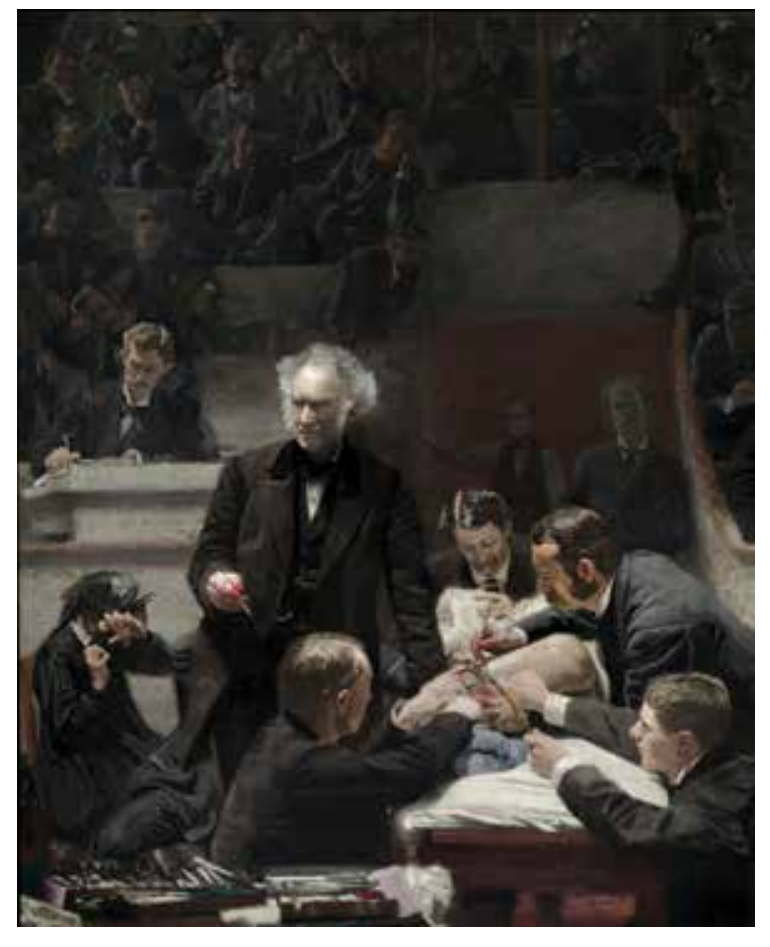

Fig. 8 of Dr. Samuel D. Gross (The Gross Clinic), 1875. Oil Museum of Art (artwork in the public domain and obtained via www philamuseum.org).

the powerful influence of John Ruskin-into a language of transcription. In the third of his "Letters on Landscape Painting" published in New York's newly founded art journal The Crayon in 1855, Durand claimed: "Every truthful study of near and simple objects will qualify you for the more difficult and complex; it is only thus you can le to to read the great book of Nature, to comprehed it, and eventually transcribe from its pages, and attach to the transcript your own commentaries. ${ }^{16}$ His own exhibition pictures typically accompanied by competing explanatory texts, Church too embraced this language of transcription. ${ }^{17}$ Outlining a scheme to ship The Heart of the Andes to Germany so its massive form could be viewed by eminent natural philosopher Alexander von Humboldt, he claimed his painting as a species of the scrivener's art. Church wished to show Humboldt a transcript of the scenery which delighted his eyes sixty years ago."

Attending to oft-baffled responses of period viewers to the insistent details of Church's sprawling canvases, Jennifer Raab has recently pressed on the ways in which this literary signification could devolve into cacophonous, polysemantic volubility. Church's pictorial enterprise, she argues, "runs the risk of always being in the process of speaking, and of never saying just one thing." ${ }^{\prime 19}$ To build on Raab's language of details and risk, it is worth underscoring that Church's on Raab's language of details and risk, it is worth underscoring that Church's
pictorial schemes can also be seen as importantly numerical (see fig. 7). Consider again Church's Cayambe sketch: in addition to the caption at center-right identifying the location and date of the overall view ("Cayambé from Hill of the Templo del Sol, June 24th/57"), the painter has employed a simple numerical code. The number three inscribed just above the ridge at left is keyed to a legend below, where the number is identified with the Valle de Chillo.
Although this practice of numbering and annotating drawings has merited only passing comment in histories of American painting, Church used it extensively (fig. 9). ${ }^{20}$ The efficiency of this coordination between number and text within pictures can be grasped through comparison to one of Church's earliest annotated drawings: a sketch of a dockside fire that engulfed the wharves of Hudson, New York, on June 28, 1844. Leaving most of the graphic surface bare of pictoial incide $\mathrm{Ch}$ (h) tial incident at centerleft, its his small, off-white card through rapid hatchings might well have captured optical values Church then observed. But the fire's outbreak at night posed a graphic challenge. In fact, the painter offers little attempt to make nocturnal darkness visible through pictorial means; he simply states it with the parenthetical word night," which floats above the scene. The word thus prompts the viewer to imaginatively invert the sketch's optical values so that the untouched expanse of page above the forest of pencil-work ascending as smoke at right reads as dark rather than the literal light we see. Intuitive as this substitution likely was, Church also makes more deliberate interventions to signal chromatic effects. As the key at he page's base explains

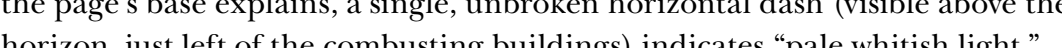
horizon, just left of the con Stacked, parallel dashes that act as a sign of equivalence in mathematical relations (directly below the town) here denote a "reddish" hue, while an exaggerated letter "e" (visible in the spreading smoke-form at upper right) signals that "the smoke grows gradually indistinct" from the encapsulating shadow of night.

Notations of this kind present what philosopher Nelson Goodman calls semantic ambiguity. ${ }^{21}$ Is the half-moon shape directly left of the burning town a depiction of the crepuscular moon visible on that June night when Hudson combusted? Or, should it be read as a symbolic character cued to the similar claw-like form

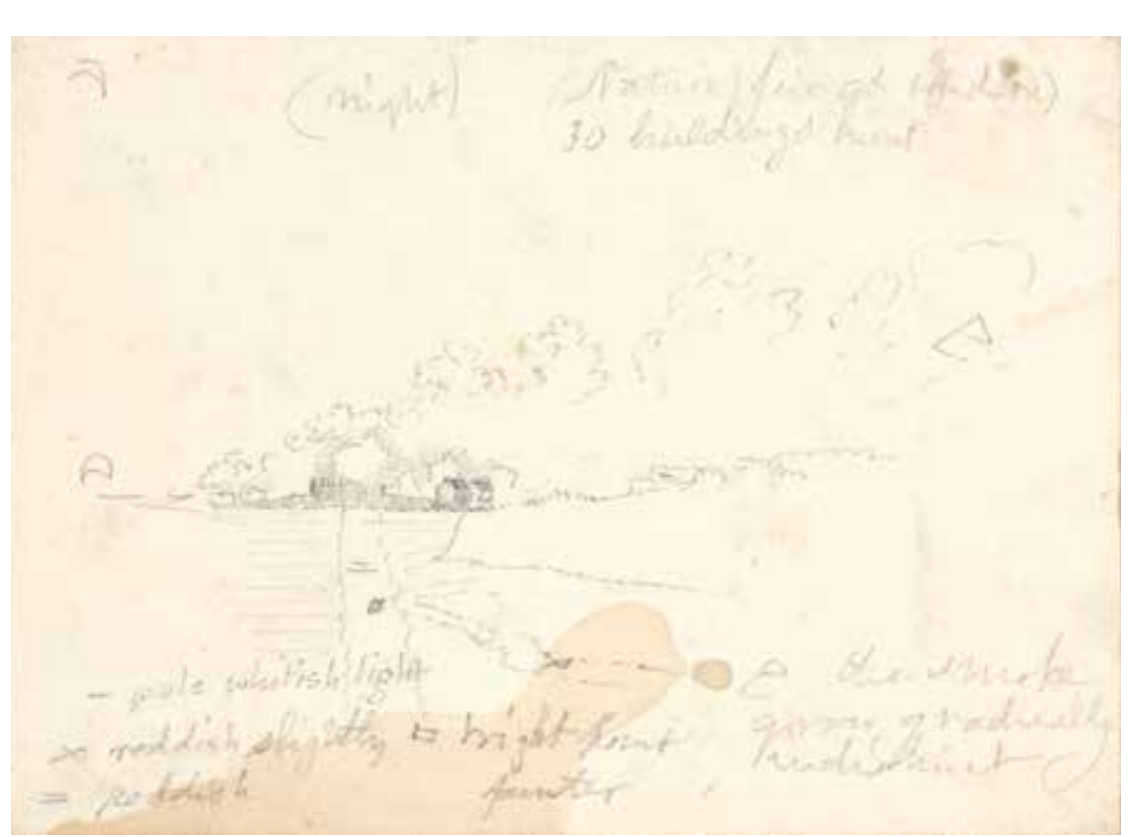




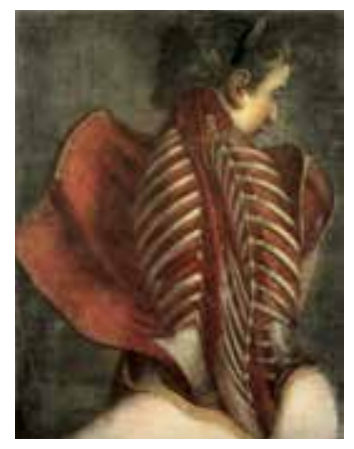

Thomas Cole, Horseshoe 1829. Pen and brown ink
over graphite pencil on offwhite wove paper. Detroit Institute of Arts (Founder Society Purchase, William Falls, Niagara, Morning, ca.

Fig. 10

d'Agoty, Muscles of the Back

in a Female, ca. 1745-46.

Color mezzotint. Wellcom

in the public domain

and obtained via http://

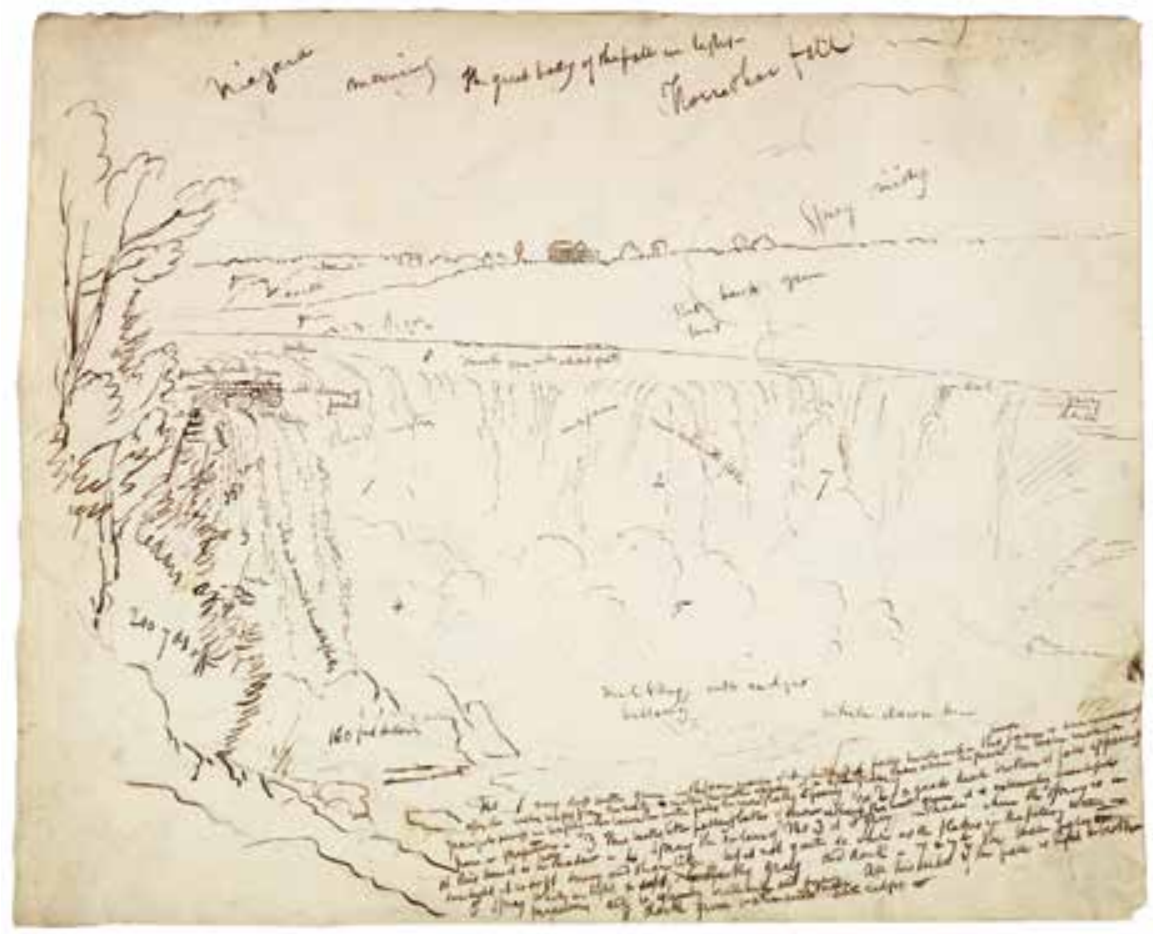

directly above it, thereby acting as key to the parenthetical legend "night"? Given the extensive library of scientific texts Church amassed at his eccentric home in the Hudson River valley, it is tempting to imagine that he might have abandoned these early quasi-naturalistic reference characters for alphanumeric notational systems standard to natural-philosophical publications since at least the later seventeenth century (fig. 10). ${ }^{22}$ However, in 1844, Church could have found an elegant solution to his referential ambiguities in a practice developed by Thomas Cole, the British-born landscape painter with whom Church was the studying (fig. 11). Sketching Niagara Falls in 1899, Cole produced a drawing bristles with mus th bristles with multimodal visual information. Jagged pen strokes at left effect a shaggy repoussoir of overhanging trees and bushes. These hatches turn linguistic (the word "Cedars" is legible, slanting diagonally toward the depths of the falls) and numerical as Cole denotes distances within and through the landscape. That crooked escarpment at near left stands "200 yards off," while the milky floor of the thundering falls lies "160 feet below." Further, Cole employs a numbering system to signal chromatic phenomena of a kind difficult to make visible through pictorial means of ink on paper. Keyed to the number 8 , the horizontal zone of bare paper at the summit of the falls is characterized at the base of the page as "dark green water with small white ridges.". ${ }^{23}$

Cole's numerical method of annotation thus eliminates much of the semantic confusion between pictorial marks and symbolic characters besetting Church', early Fire at Hudson In fact, in his mature handling of the convention, Church introduct an in the

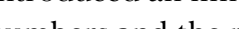
numbers and the pictures into which they were enbedded (fig. 12). As seen in this sketch of a rocky promontory made off the coast of Maine in August 1850, Church nearly always left the numerical character "1" out of his annotative schemes. An ambiguous form, "1" could easily read as a numerical unit, as an alphabetical character (such as the letter "l" or " $i$ "), or as a graphic feature of the pictorial world into which it was inserted. Instructively, Church's drawing practice of the 1850s typically abandons it, beginning the annotative program instead with number 2. As visible here, it reads "2-white barnacles[;] 3-yellow ditto[;] 4-rock weed[;] 5-Dark stone[;] 6-yellow and rusty light."

Church's ability to transform these provisional pictures with their numerically keyed annotations into monumental showpieces like The Heart of the Andes also

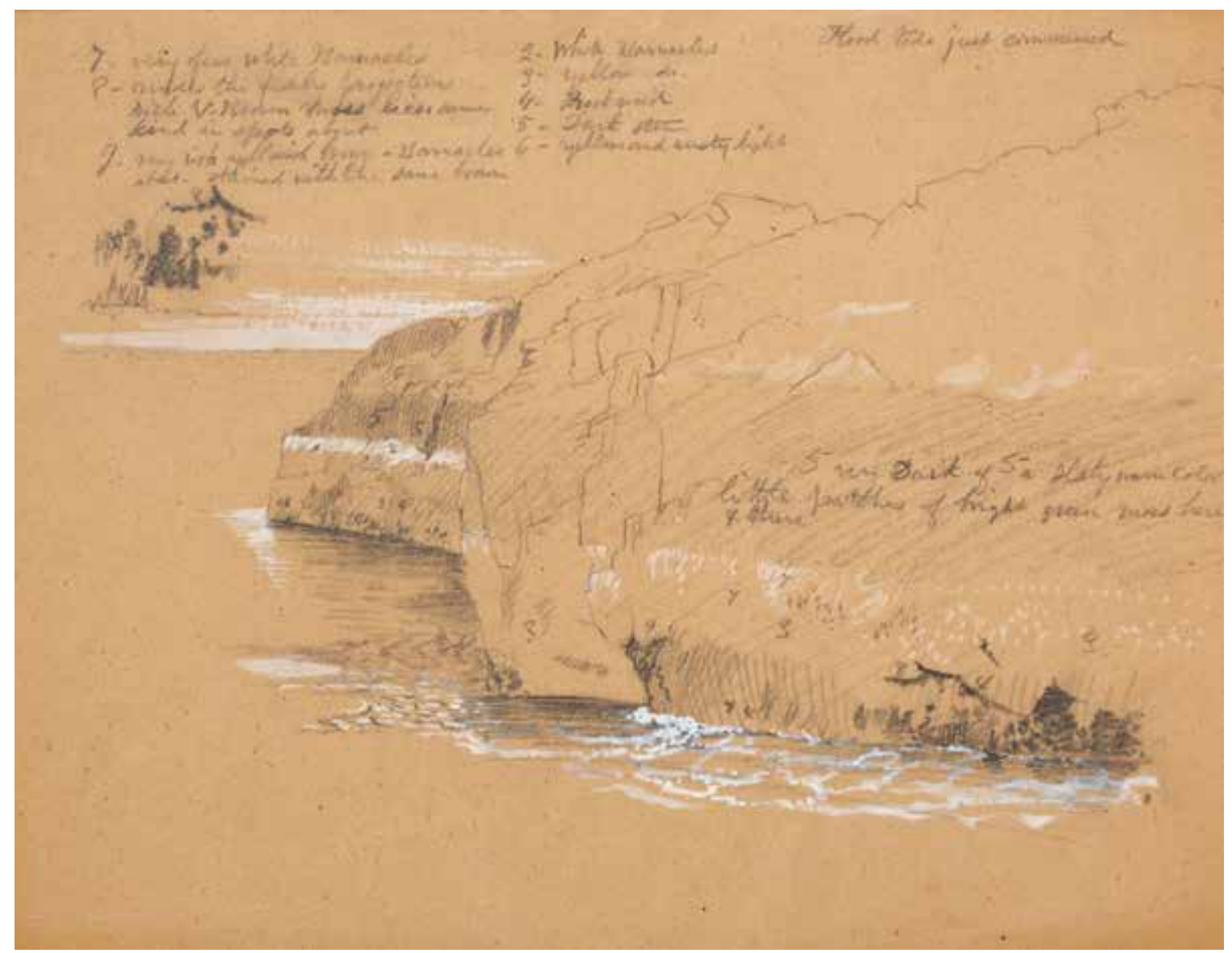


foregrounds the painter's head for numbers in a different sense: an entrepreneurial savvy that has been stressed by nearly all his interpreters. ${ }^{24}$ After all, Church painted that picture "on spec" and exhibited it at Richard Morris Hunt's then recently opened Tenth Street Studio Building in Greenwich Village, charging twenty-five cents per head to the roughly twelve thousand people who saw the picture in April 1859. By the end of that year, he had sold the painting to a William Blodget of New Vok City for ten thour, he hallars, four pin the a William commanded for his prize-wining painting or No Shown in London in the summer of 1859, The Heart of the Andes was shipped back across the Atlantic for exhibition in Baltimore, Boston, Chicago, Cincinnati, Saint Louis, and elsewhere, as Church contracted with the Glasgow-based publishing firm of James McClure and Sons, allowing them to continue exhibiting the painting for an additional two years. Further, Church negotiated a contract with Blodgett stipulating that the painter could break their agreement if he could find another American buyer willing to pay twice again Blodgett's price within two years of their transaction. And, while he sold the image's copyright to his $\mathrm{Cl}$ segow printers, Church also retained half the profts from the sale of prints of the picture as engraved by William Forrest.

What I mean to stress by this tour de force of numerate financial acumen is the following. As much as it mobilized ut pictura poesis tropes trumpeting ennobling relations to literature, the domain of images that was mid-nineteenth-century American landscape painting in the so-called Hudson River School of Cole and Church needs also to be seen as triangulating its pictures and texts through the medium of numbers. ${ }^{25}$

\section{Thinking through Photostats}

Whatever precisely motivated the use of the technique in 1949 when copying the sketchbook borrowed from Mrs. Theodore Winthrop Church of 212 East 48th Street, it is crucial to note that replicating numbers, pictures, and other complex mixtures of notation had long been vaunted as particular strengths of the photostat. In The Photostat in Reference Work (1920), librarian Charles F. McComb underscored the voracious appetite for inexpensive reproductions of statistical tables and sheet music among the New York Public Library's research clientele. As McCombs put it: "For no other two classes of printed matter is the use of the photostat more important than for tables of statistics, and music. A wrong figure or a false note may produce disastrous consequences ${ }^{\prime 26}$ Photostat is the proprietary name for a dedicated camera and printing technique, which exposes an etary image of the ary a prismatic mirror (fig. 13). "First introduced into major research libraries in the second decale of by the mid-1930s as an easy-to-use technique for cheap and rapid replication.

To make a photostat, the operator places the item for replication on a holder in front of the metallic instrument stand. Camera focus would be achieved entirely through mechanical means; fitting the target object into a matrix of rectangles cut into a moveable bed, the user notes the relevant rectangle's
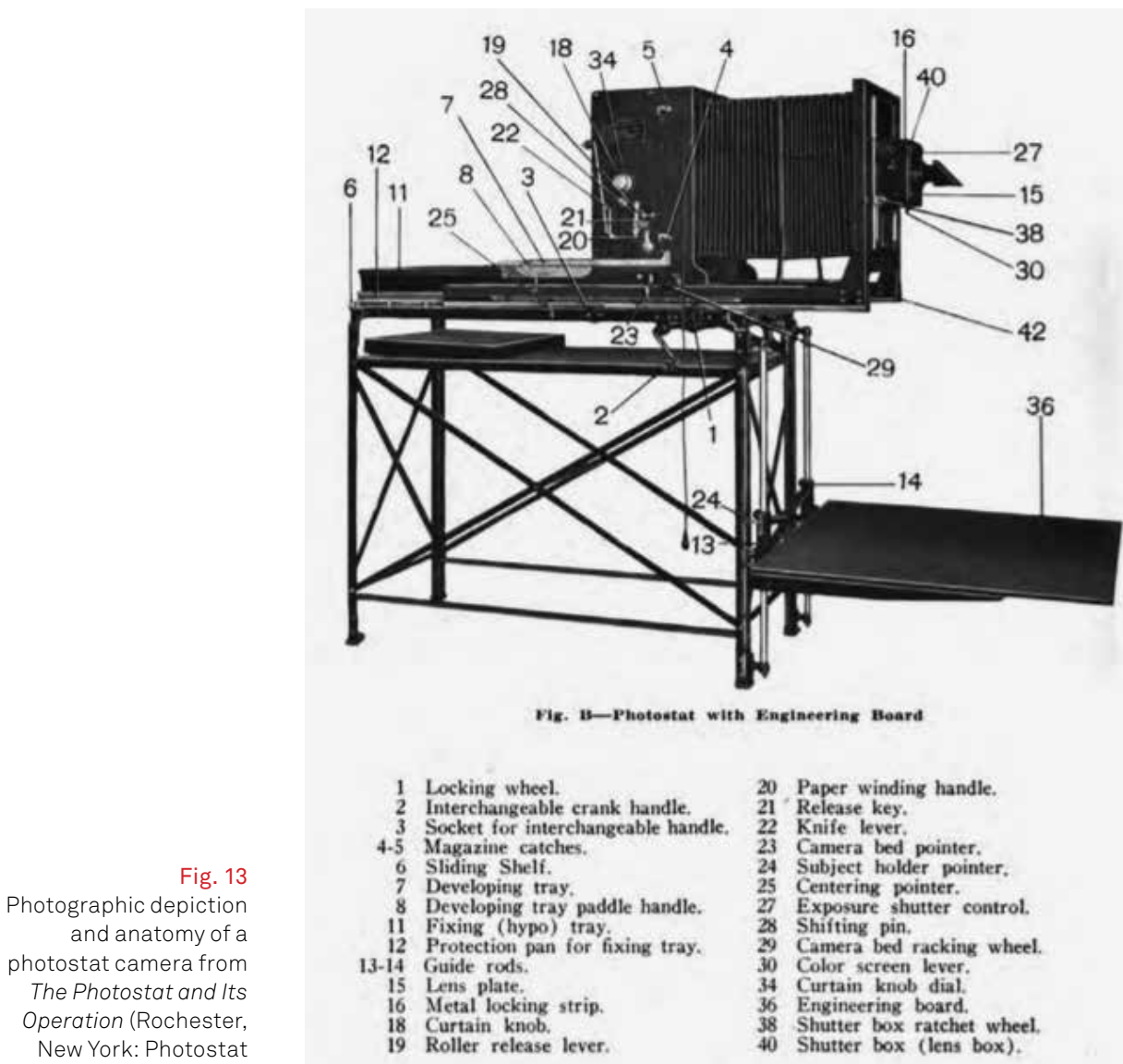

Operation (Rochester,

New York: Photostat

16 Metal locking strip.
18 Curtain knob.
19 Roller release lever.

preassigned number and moves the camera bed racking wheel (no. 29 in fig. 13) until the camera bed pointer (no. 23) is affixed at the corresponding number. Evenly illuminating the target with mercury vapor lamps, the operator sets the lens at the suggested f-stop and pulls the shutter cord, exposing for some five to eight seconds the sensitized paper held in the device's central magazine. ${ }^{20}$ While gelatin papers were recommended for reproduction-quality prints, woven bromide paper-similar to that used to reproduce Church's sketchbook-was standard for research use..$^{29}$ The operator then closes the shutter, winds the exposed paper out of the magazine, and releases a knife lever (no. 22) to cut off the imprinted paper. Having previously filled the tray with chemicals specially prepared for the deve by prepared for the cut paper into the machine's developer (no. 7) and leaves it there for thirty-five to forty-five seconds. Mechanically squeegeed of excess chemicals as it winds out of the developer, the print is immersed face down in liquid fixative, then dried on blotting cloths. ${ }^{30}$

By the time Church's sketchbook was reproduced in 1949, the photostat faced a major technological rival in the institutional replication of documents: microfilm. Not only did that competitor enjoy the frisson of association with emergent 


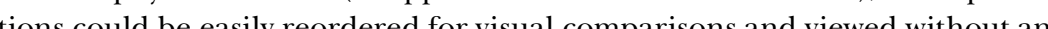
elaborate technical interface. Yet, while it has figured but modesty against lantern slide, the image library, and other visualization techniques crucial to the history of art-historical knowledge production, the photostat would be appropr ated by practicing artists of the 1960s, folded into what Benjamin Buchloh has called conceptual art's "aesthetics of administration. ${ }^{.32}$ For artists such as Joseph Kosuth, the technique's anonymity and deskilled, mechanical reproduction made the photostat crucial to the brand (and branding) of conceptual art. ${ }^{33}$ Speaking in a "vernacular of administration," Kosuth's photostats have indeed gone on to anticipate the bureaucratic structures of museological governance that their contractual "certificates" pledge. ${ }^{34}$

What might be learned by thinking Church through the thickness of the photostat's bureaucratic mediation? Usual stories tell us that mid-nineteenth-century Americans were hardly paragons of bureaucratic acumen. Although Alexis de Tocqueville had been able to admire their vigor for a "life liable to mishaps but full of striving and animation," he also cautioned European readers abou Americans' commitment to paperwork: "It is no good looking in the United States for uniformity and permanence of outlook, minute care of details, or perfection of administrative procedures. ${ }^{355}$ Few Americans would have contested that characterization more vociferously than the emergent ranks of insurance underwriters matering financilints as guardians of freedom amid the hazids of life und the hazards of life Insurance Company in Hartford, Connecticul-the business where Joseph Church, the painter's father, served on the board of directors for forty-three years-grounded the mathematical predictability and financial viability of their enterprise upon their agents' meticulous reports. ${ }^{37}$ Against the view of insurance as "luck, of mere chance," they stressed that the actuary's calculations could in fact "be accomplished with a good degree of certainty, if the business is properly attended to in all its details. And no business of the aggregate extent of ours is so dependent upon details.”

Able agents were needed to amass those details. When it emerged in American insurance of the 1830s-1840s, so writes historian Sharon Ann Murphy, the agency system was conceived "not as a sales force but as a means of repersonalizing the connection between corporate headquarters and the individual alizing the connection between corporate headquarters and the individual
applicant ... allow[ing] companies to navigate successfully between the world of personal relationships and anonymity. ${ }^{\prime \prime 9}$ Corporations operating across the mid-century insurance industry stressed the need for their agents to be upstanding citizens, firmly entrenched in their communities, and thus commanding extensive knowledge of applicants' livelihoods and credibility. ${ }^{40}$ But fire insurers such as Aetna also developed more material techniques for converting confusing

SAMPLE DIAGRAM

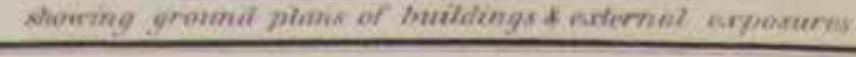

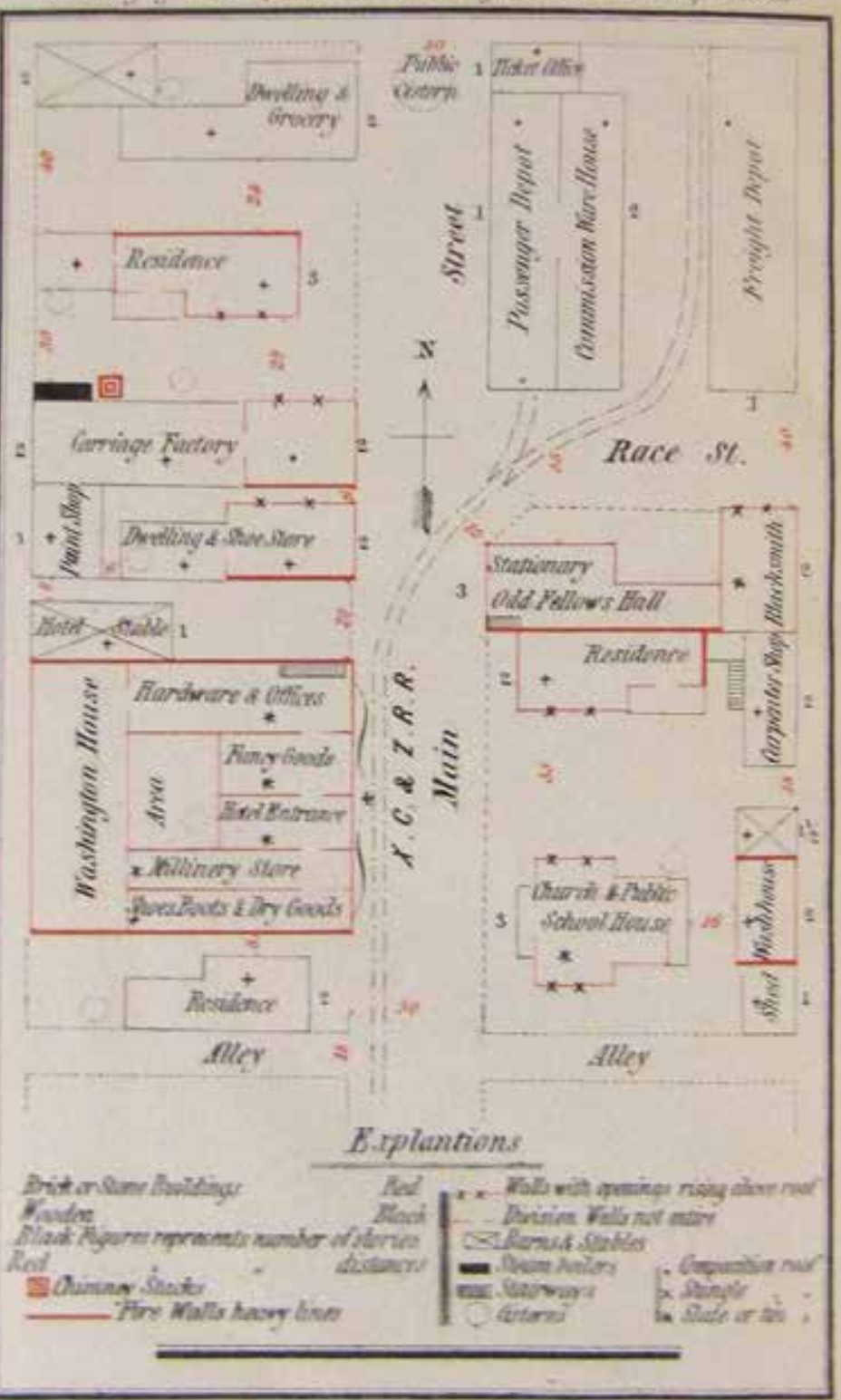


observations and conflicting narrative into prudent numbers. As a guide for new agents who were most liable to "take undesirable risks and at rates that would be rejected by those more experienced," Aetna outlined protocols for reports, which would be sent to the central office for expert adjudication. ${ }^{41}$ Significantly, the act of drawing figures centrally in this reporting protocol, which is described thus: "Until experience shall enable them to determine the proper premium to charge, they [new agents] should make a careful survey, with a diagram, of all risks offered in blocks, or with questionable exposures or risks, and refer to Head-quarters to be advised as to the proper rates."24

One such sample diagram enclosed in Aetna's 1857 instruction manual offers a schematic ground plan of a modern town where forking railroad spurs bisect a collage of residential, commercial, and industrial properties (fig. 14). To the novice actuary trying to calculate its fire risk, the mixed-use Washington House on the west side of Main Street would have presented a diabolical challenge. It conjoins two discrete "unprofitable risks": the highly combustible contents of the milliner's store and the "fancy goods" shop two doors down ${ }^{43}$ Would the the nent compong this map res agesident, alle resident, all tenants occupring the mit would he recall "ase to be charged the full rate of such exta or special risk" Would he recall that a higher rate should be charged, given the danger of the hotel's shingle-roofed stable ${ }^{45}$ Would the agent implement the company's "golden rule" of never insuring property for more than three-quarters of its actual value, on the principle that "light insurance promotes carefulness, which does much toward security"? ${ }^{46}$ Finely grained calculations like these were, in the company's view, best left to the deliberation of experienced hands who could carefully assess an agent's written report and annotated diagrams together so as to produce prudent numerical values. Drawings were thus to be made in the field and returned to the head office, where they would be converted into numbers.

Seen through the refracting thickness of its photostatic mediation, Church's Yehubamba sketch answers well to this numerical drive. Targeting a named individual at a specific place and date, the drawing aggregates details separated by chronological time and pictorial space. Rendering the instruments by which this individual's most conspicuous material possession was produced, the sketch prompts recollection of the numerical asymmetries between labor time and market value embodied in that garment, and the signification of class conflic entailed thereby. Where Aetna's urban ground plans would allow the far-flun novice to diagram space and combine it with a written report that centralized experts could then convert into

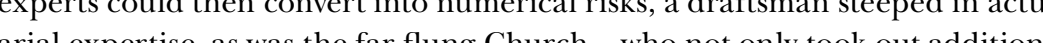
in insurance on his own life, but required The Hean of the Andes's broker to purchase ten thousand dollars of indemnity when the picture was shipped to Britain to be exhibited and engraved-could import numerically inflected details in pictorial space as he ran his own kinds of risk calculation, assaying the wealth and class status of the subject he names.

Under the sign of an expanding "domain of number," historian Patricia Cline Cohen has argued that the first two decades of the nineteenth century witnessed "the American public's sensitivity to quantified material ... considerably heightened by economic, political and social changes that were making numbers an integral part of life."18 That culture of numeracy prompts an instructive return to Church's early sketch of fire at Hudson, New York, in 1844 (see fig. 9). Noting the painter's childhood interest in visual spectacles of "fire, incandescence, and lightning" art historian Gerald L Carr has lamented that Church then and confined his depiction of Hudson's conflagration to pencil rather than oil on canvas. Nonetheless, Carr contends, "he sight recorded... proved prophetic for his art: Within a few years, the skies in his easel paintings began to blaze with celestial flames as vivid as the terrestrial ones he observed in June 1844." Focused as Carr is on the production of prestigious oil paintings that justify the art-historical genre of the catalogue raisonné he is writing, he takes no notice of a closer prompt to Church's interest in fire: the fire-indemnity interest brokered so successfully by his father. ${ }^{50}$ Against the graphic schemes of actuarial calculation later endorsed by that "Puritan businessman" (as Church's first modern interpreter, David C. Huntington, described Joseph Church), the painter's 1844 ketch might be read as a hybrid: poised in tension between annotation of the

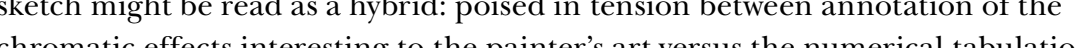
surnt") of the risks lost-those botom-lin underpin Aetna's appeal to graphic notation..$^{51}$

By contrast, the Yehubamba sketch amounts to a far more comprehensive integration of the actuarial sensibility into its graphic structure. No longer does the drawing stage some Oedipal struggle between the paternal horizontality of the graphic ground plan and the filial plane of pictorial verticality, to recall the quasi-Wölfflinian terms used by Fried. ${ }^{52}$ Shorn of the visible reference numbers so crucial to Church's contemporaneous sketching practice, the drawing instead transfers into a visible plane the details necessary for an experienced eye-for professional vision—to make numerical inferences. ${ }^{53}$ Compiling evidence of a named, dated, and placed individual's most conspicuous material possession and its means of production, the drawing asks: how can his future prospects be calculated? Historian and theorist François Ewald observes that "insurance individualizes, it defines each person as a risk, but the individuality it confers no onger correlates with an abstract, invariant norm such as that of the responsible juridical subject; it is an individuality relative to that of other members of the insured population, an average sociological individuality." ${ }^{.54}$ Concealing the figure's physiognomic features and thereby delimiting the beholder's empathetic relation to him, the drawing treats its named individual, Manuel Cuki, less as a person than as a statistic: a predictable subject of what Church had called "managerial inefficiencies," or, as we might call them, economic inequalities ${ }^{55}$

Apprehended through the photostat, moreover, Church's drawing suggests a emporality discrete from those artifacts called "preparatory sketches" favored by art-historical logic insofar as they result in the domestic, metropolitan composition of long, slow oil pictures. ${ }^{56}$ Instead, highlighted by the bureaucratic medium in which they alone survive, Church's acts of thick-slicing enable us to watch nineteenth-century American landscape painters engaging with otherness (tropical, in this case) by transferring techniques for gauging life-techniques increasingly central to the mental furniture of their numerate patrons 


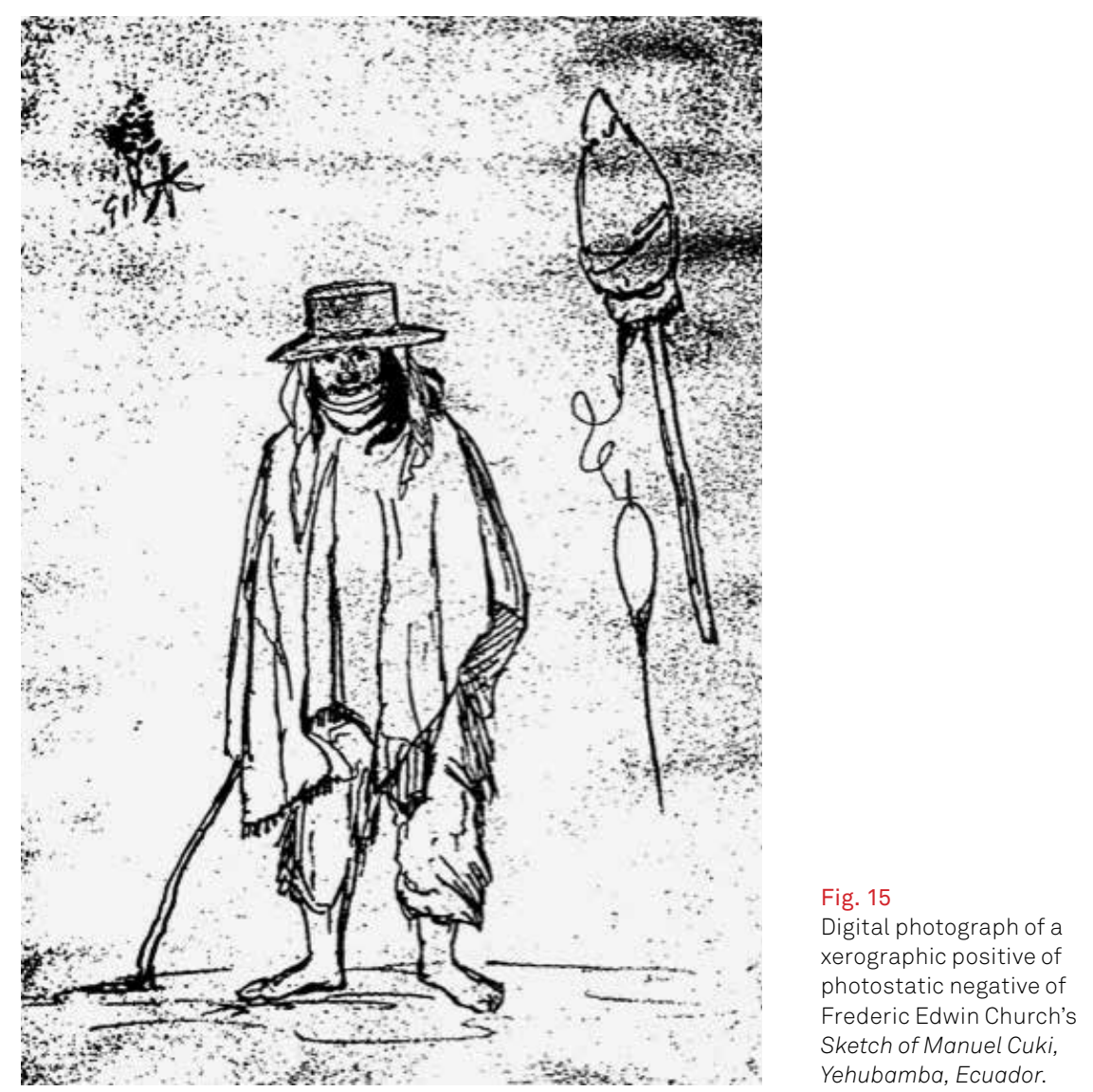

and audiences. ${ }^{57}$ Building these skills of actuarial knowing into the fabric of graphic making, Church's sketch allows us to watch how not only finished oil paintings but the uncertain, future vagaries of human existence were themselves coming to be made calculable by numbers.

\section{From Transfer to Countertransference}

Writing in 1960, psychoanalyst Hans Loewald decried the manner in which his professional colleagues subscribed too quickly to an ethics of detachment drawn from the prestigious "exact sciences." The analyst only too willingly sees dra herself, Loen childhood devepted reactivated in the development, crystallization and resolution of the transference neurosis, but as a reflecting mirror ... and characterized by scrupulous neutrality. ${ }^{58}$ Yet, to those practicing the classical Freudian model where the patient's transference onto the analyst proves crucial to therapeutic effect, such glib appeal to a rhetoric of neutral detachment was positively pernicious. Rathe than endorsing objectivity, Loewald charged, the analyst's brief was to help the patient to reform object relations-and to do so by a peculiar kind of mediation.
He puts it this way: "Undistorted reality is mediated to the patient by the analyst, mostly by the process of chiselling away the transference distortions, or, as Freud has beautifully put it using an expression of Leonardo da Vinci, per via da levare as in sculpturing, not per via di porre as in painting. ${ }^{.59}$ The analyst doesn't fill in the blanks offered by the patient, but instead enacts therapeutic effect by using negative means to pare down the image of self revealed by the patient in ung the the analyst has to focus in his mind, thus holding it in safe keeping for the patient to whom it is mainly lost. It is this tenuous reciprocal tie which represents the germ of a new object-relationship." ${ }^{60}$ For Loewald, a more robust understanding of psychoanalysis's therapeutic efficacy required acknowledging a mediating role for the analyst, which exceeded the inherited bounds of objective science. Only by that means could it open a productive space for the role of countertransference, of the analyst's projections back onto the patient.

This essay has sought to trace the dynamics of making and knowing at several Thels, both in Church's contemporar . Church makes his sketch of Manuel Cuki by marshaling his knowledge of Andean textile production. Building upon the alphabetico-numerical techniques of sketching he imbibed through Thomas Cole's artistic pedagogy, I have argued, the painter's integrative rendering moves with and beyond the graphic strategies for actuarial knowing then being endorsed by an American insurance industry in which his father figured significantly. In turn, that nexus of graphic making and actuarial knowing has become visible by attending to the material heft of the bureaucratic medium in which Church's Yehubamba sketch now survives.

And, to come clean by way of return to Loewald, that mediated sketch is the the with arch that eseach into which this article has sought to return Church, my own attention to documentary detail was woeful (fig. 15). When I left the archive in late summer of 1999 with this image in hand, not only had I failed to note that it was a positive xerographic reproduction of a negative photostat of a now-lost sketchbook (that photocopy seen here in digital rendering). I had even managed to crop out the textual legend detailing the figure's name, date, and location. Acknowledging my own affective engagement while working backward like Loewald's analyst to winnow out the most egregious of these distortions, this article has sought to foreground the positive thickness of its mediations. Paperwork, as Ben Kafka has recenty oberved, not only requires "a theory of praxis... it also requires has recen obs form of com form of communication, is subject to unconscious forces. By bringing midcentury American landscape drawing back into dialogue with period practice of actuarial paperwork, my own unconscious slips might too be guided to an unlikely end. As with risks lost to the agent through insufficient attention to detail, so the Yehubamba sketch returns not offering but-like an injured policyholder-demanding redemption. 


\section{Matthew C. Hunter}

Matthew C. Hunter teaches in the Department of Art History and Communication Studies at McGill University. Author of Wicked Intelligence: Visual Art and the Science of Experiment in Restoration London (University of Chicago Press, 2013), he researches visual art and architecture of the long eighteenth century, with special emphasis on their intersections with science and technology.

I am pleased to thank Pamela $\mathrm{H}$. Smith for the invitation to contribute to this special issue, along with Dan Lee, the anonymous referees, and Jeffrey Schier at West 86 th. My thanks to Ida Brier,
Valerie Balint, and Ronna Dixon at Olana State Historic Site; Shaun Kirkpatrick and Kristind Wilson at Chubb Archives; Jeanne Solensky at Winterthur Library; as well as Charles Gagnon and Sharon Ann Murphy. Jason LaFountain, Jennifer L. Roberts, Jennifer Raab, Jennifer Chuong, Joh Brewer, Zeynep Celik Alexander, Avigail Moss, and John Harwood all read versions of this essay; I thank them for their incisive comments even if my responses have fallen short of their suggestion Newberry Library; thanks, respectively, to conveners Iris Moon and Claudia Swan, J. B. Shank, an
Rebecca Zorach, along with fellow participants and interlocutors at those events for their feedbac particularly Richard Taws and Michael Gaudio. This essay is dedicated to Joel Snyder, who endured chinital manifestations with quich in

Compare Marcellus Laroon, The Cryes of the City of London Drawne after the Life (London: Pierce Tempest, 1689); Henry Mayhew, London Labour and the London Poor [1851] (London: Charles Griffin
and Company, 1864). I owe the latter comparison to Avigail Moss, whom I thank heartily. For more on and Company, 1864). I owe the latter comparison to Avigail Moss, whom I thank heartily. For more on the "cries" genre, see Sean Shesgreen, Images of the Outcast: The Urban Poor in the Cries of London (New
Brunswick, NJ: Rutgers University Press, 2002). For a different reading of the problematic of facing . 1860 s (Chicago: University of Chicago Press, 1996.).

2 F. E. Church to Eliza Church, August 20, 1853; Joseph E. Downs Manuscript Collection, Winterthur Library, 66, Folder 20: 40.

Kipling and his drawings, see Tim Barringer, Men at Work: Art and Labour in Victorian Britain Church to Fliza Church Puss 20, 1853. 281-92.

5 F. E. Church to Joseph Church, June 9, 1853; Joseph E. Downs Manuscript Collection, Winterthur Library, 66, Folder 20: 35. Church simultaneously used this terminology in the journal he kept in Spanish during the 1853 trip. In Bogotá on June 8, 1853, Church wrote: "Hoy Bogotá está mucho
excitado por una collision o' affravment entre los jovens o casacas o cachacas y los pueblos o ruases Frederic Edwin Church's South American Diary. May-Oct. 1853; OL.1980.27, Olana State Historic Site, Hudson, NY

6 On this conflict, see Pablo Navas Sanz, The Journey of Frederic Edwin Church through Colombia and

7 Michael Baxandall, Painting and Experience in Fiffeenth-Century Italy (New York: Oxford University

8 Lorraine Daston and Peter Galison, Objectivity (New York: Zone Books, 2007), 337. Interestingly, Daston and Galison trace the roots of trained judgment back to Alexander von Humboldt, a Germa natural historian who has figured significantly in the interpretation of Church 's South American

Mictures; see Abert Ten Eyck Gardner, Scientic Sources of the Full-Length Landscape: 1850 ,"

Humboldt, and Darwin: The Tension and Harmony of Art and Science" in Frederic Edwin Church ed. Franklin Kelly (Washington, DC: National Gallery of Art, 1989), 94-107.

9 See Nalini Ambady and Robert Rosenthal, "Thin Slices of Expressive Behavior as Predictors of also Malcolm Gladwell, Blink. The Power of Thinking without Thinking (New York: Lit): 256-74. Sec On the older epistemic privilege of information accessible to a single coup d'oeil, see Kristel Smentek "The Collector's Cut: Why Pierre-Jean Mariette Tore Up His Drawings and Put Them Back Together Again," Master Drawings 46, no. 1 (2008): 36-60.

10 On this calendrical rhythm in Church's sketching practice, see, for example, Theodore E. Institution Press, 1978); Franklin Kelly and Gerald L. Carr, The Earry Landssapes of Frederic Edwin Church 1845-1854 (Fort Worth TX. Amon Carter Museum, 1987): and Andrew Wilton et al Frederic Church and the Landscape Oi Skeech (London: National Gallery, 2013). Church's first moder biographer, David C. Huntington, quotes an account from 1879 claiming that Church "generally
.

Although appeal to cognitive style is not one I make in this essay, such an approach is variously taken in Horst Bredekamp, Vera Dünkel, and Birgit Schneider, The Technical lmage: A History of Styles in Scientific Imagery (Chicago: University of Chicago Press, 2015).

2 Heinrich Wölfflin, Principles of Art History: The Problem of the Development of Style in Later Art, 7th ed.

13 Michael Fried, Realism, Writing, Disfiguration: On Thomas Eakins and Stephen Crane (Chicago:
University of Chicago Press, 1987), 22-38. For the influence of Fried's study upon histories of University of Chicago Press, 1987), 22-38. For the inluence of Fried's study upon histories of (2006): 42-44. See also Bryan J. Wolf, Romantic Re-Vision: Culture and Consciousness in Nineteenth
(2) American Painting and Literature (Chicago: University of Chicago Press, 1982).

14 For a summary of this argument, see Fried, Realism, esp. 80-89, 175-78.

15 Clement Greenberg, "Towards a Newer Laocöon" [1940], in Clement Greenberg: The Collected Essays and Criticism, vol. 1, Perceptions and Judgments, 1939-1944, ed. John O'Brien (Chicago: University of Chicago Press, 1986), 1: 29.

1, "ters on Landscape Painting: Letter III," The Crayon 1, no. 5 (Jan. 31, 1855): d for pressing me on the role of Ruskin here, even though I have not done 17 Compare, for example, Rev. Louis L. Noble, Church's Painting. "The Heart of the Andes" (New York; D. Appleton, 1859); and Theodore Winthrop, A Companion to "The Heart of the Andes" (New York: D. Appleton, 1859).

win Church to Bayard Taylor, May 9, 1859, cited in John K. Howat, Frederic Church (New CT: Yale University Press, 2005), 88

19 Jennifer Raab, "Precisely These Objects': Frederic Church and the Culture of Detail," Art Bulletin 95, no. 4 (2014): 584 .

20 See for example Gerald L. Carr, Frederic Edwin Church: Catalogue Raisonné of Works of Art at Olana asserts that, as symptoms of the painter's increasingly "scientific" orientation to South American sites during his 1857 journey, Church made "more extensive use of the shorthand numbering system he had been using in North America to record fleeting effects as rapidly and as accurately as possible Katherine Manthorne, Tropical Renaissance: North American Artists Exploring Latin America, 1839-1879 fascinating account of Church's later enumerated prints that struggled to make his exhibition the Holy Land in Nineteenth-Century American Art and Culture (Princeton, NJ: Princeton University Press, 1996), 187-92.

21 See Nelson Goodman, Languages of Art: An Approach to a Theory of Symbols (Indianapolis: Hackett,

On these conventions, see Matthew C. Hunter, Wicked Intelligence: Visual Art and the Science of Experiment in Restoration London (Chicago: University of Chicago Press, 2013), esp. 139-46.

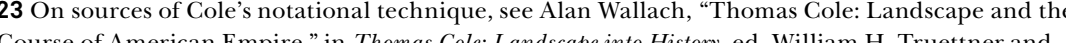
Course of American Empire," in Thomas Cole: Landscape into History, ed. William H. Truettner and

wn venality; see Great Britain: The National Gallery Watercolor of The Heart of the Andes," Studies in the History of Art 12 (1982): 81-100; and Kevin J. Avery, Church's Great Picture, "The Heart of the Andes" (New York Metropolitan Museum or $\mathrm{D}$,

法 . copying, 1780-1938 (New Castle, DE: Oak Knoll Press, 1999), 159-60; and H. R. Verry, Doccument Copying and Reproduction Processes (London: Fountain Press, 1958), 148-50.

ester, NY: Photostat Corp., ca.

the 1940s, and the 1950s," Microform Review 18, no. 3 (Summer 1989): 145.

30 Photostat Corporation, Photostat, 22-23.

no. 3 (Summer 1989): 145 . Bourke, "Photostat-Microfilm War," 1

(Dec. 1988): 295-301 Spyilm: The

the Critique of Institutions," October 55 (Winter 1990): 105-43. On art historical image-technics to among others Helene E. Roberts, ed., Art History through the Camera's Lens (Amsterdam: Gordon and 
34 For "vernacular of administration," see Buchloh, "Conceptual Art," 142. More broadly, on

Tables," unpublished essay. I thank Charles Gagnon for sharing his work with me.

J5 Alexis de Tocqueville, Democracy in America, ed. J. P. Mayer, trans. G. Lawrence (New York: Harper and Row, 1969), 93, 92

Capitalism compelling Risk iecent account, see Jonathan Levy, Freaks of Fortune: The Emerging World of

Etna Insurance Company, Hartford, Connecticut, 1819-1919 (Hartford, Conn: Etna Insurance Co, 1919,

226.

Aetna Insurance Company, Instructions for Agents (Hartford, CT: Aetna, 1857), 6

Aetna, Instructions, 11

40 Ibidi., 7 .

42 Ibid., $7-8$.

43 See ibid., 25

45 See ibid., 47

46 Ibid., 9.

47 On Church's insurance purchases, conparo Navas Sanz, Journey of Fredenic Edwin Church, 165 n. 7 ,

and Avery, Church's Great Picture, 34

University of Chicas

49 Carr, Church: Catalogue Raisonné, 1: 43. For an interesting observation of searing experiences with fires in the artistic career of William Hogarth, see Robin Pearson, "Fire, Property Insurance and Perceptions of Risk in Eighteenth-Century Britain," in The Appeal of Insurance, ed. Geoffrey W. Clark

- Art Online Oxford Art Online Oxford University Pressnné, see Alex Ross, "Catalogue,"

oxfordartonline.com.proxy3.library.mcgill.ca/subscriber/article/grove/art/T014856.

51 Huntington, Landscapes, 21.

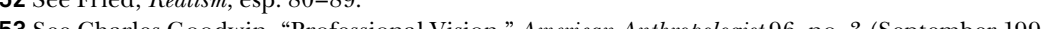

606-33.

54 François Ewald, "Insurance and Risk," in The Foucault Effect.

(Chicago: University of Chicago Press, 1991), 203.

55 An interesting comparison might be made here to Warter Benn Michael s reading of

by capitalism as ... a structural principle of capitalism"; see Walter Benn Michaels "The Beauty of a

Social Problem (e.g. Unemployment)." Twentieth Century Literature 57 (2011): 321 . "The Beauty of

56 For example, Kelly and Carr, Early Landscapes, 53, 61, 75 .

57 See classic statements including Theodore M. Porter, The Rise of Statistical Thinking, 1820-1900 (Princeton, N: Princeton University Press, 1986); and Lorraine Daston, "The Domestication of Risk: (Cambridge, MA: MIT Press, 1987), 1: 237-60.

58 Hans Loewald, "On the Therapeutic Action of Psychoanalysis" [1960], in Papers on Psychoanalysis (New Haven, CT: Yale University Press, 1980), 223.

59 Ibid., $225-226$.

61 Ben Kafka, The Demon of Writing.: Powers and Failures of Paperwork (New York: Zone Books, 2012) 111

\section{with Human Hair and Knowing How to "Listen" to the Dead}

arch, King's College,

London, United Kingdom

This essay discusses some of the ways in which human hair and bones may be perceived as materials that "speak" to us. It examines the craft skills and beliefs associated with incorporating human hair into mourning artifacts during the seventeenth to nineteenth centuries in northern Europe and North America. In addition, it compares these ways of making and knowing how to listen to the dead with the "deaf ear," which was turned by scientific collectors to the skulls they amassed in great numbers in museums during the Victorian colonial period. It concludes with an account of how the author has taken her practice as a contemporary artist in new directions in recent years_learning the skills and applying the knowledge of nineteenth-century amateur hairworkers to make a new commemorative hair wreath, which encourages reflection on a historical legacy that has led to claims for the repatriation of ancestral bones from museum collections.

The Strings He Framed of Her Yellow Hair, Whose Notes Made Sad the Listening Ea

In The Twa Sisters, a folk song collected by Francis James Child at the end of the nineteenth century, the hair and bones of a murdered princess are made into a musical instrument that spontaneously plays, denouncing the girl's assassin to her parents and their courtiers.' ${ }^{1}$ The Twa Sisters is representative of a long tradition in the arts that recognizes the potential eloquence of human remains and heir capacity to testify to the former lives of which they were once part. Citing

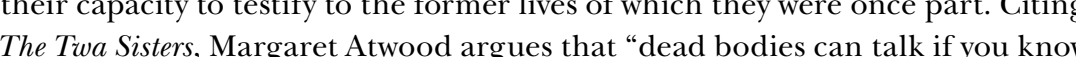
" down beside them and hear their sad stories." ${ }^{\prime \prime}$ This article discusses the use of human hair as a material that can "talk" to us and examines some of the craft 